\title{
EFFECT OF DIFFERENT CONCENTRATIONS OF SODIUM DODECYL SULFATE, EGG YOLK AND GLYCEROL ON THE FREEZABILITY AND DNA INTEGRITY OF ARABIAN STALLION SPERMATOZOA
}

\author{
EL-BADRY, D.A. ; ABEER M. ANWER ${ }^{* *}$ and RAWASH, Z.M. \\ *Dept. of Artificial Insemination and Embryo Transfer and Immunology. \\ ** Immunopharmacology Unit, Animal Reproduction Research Institute, Agriculture Research Center, Giza, Egypt. \\ Email: diyabadry@hotmail.com
}

\section{ABSTRACT}

Received at: 17/2/2014

Accepted: 24/3/2014
The present study aimed to investigate the effect of different concentrations of sodium dodecyl sulfate (SDS), egg yolk and glycerol on the freezability and DNA integrity of stallion spermatozoa. Semen samples were collected from 7 Arabian stallions, centrifuged, extended in INRA-82 supplemented with different concentrations of SDS $(0.00,0.01,0.02,0.03$ and $0.04 \%)$, egg yolk $(5,10,15$ and $20 \%)$ and glycerol $(3,4,5,6$ and $7 \%$ ), and processesed for cryopreservation. Postthaw motility, acrosome and membrane integrity of spermatozoa were assessed and comet assay were applied to determine DNA integrity of spermatozoa. Results showed that the addition of appropriate concentration of SDS is fundamental for equine semen cryopreservation. SDS, egg yolk and glycerol at concentrations of $0.03 \%, 15 \%$ and $5 \%$, respectively, resulted in the optimum motility, acrosome, membrane and DNA integrities of equine spermatozoa. Increasing the concentration of glycerol above 5\% appeared to have deleterious effect of sperm DNA manifested as increased in the percentage of fragmented DNA, DNA content in tail of comet, tail length and Olive tail moment. In conclusion, $0.03 \%$ SDS, $15 \%$ egg yolk and $5 \%$ glycerol are the optimum concentrations for cryopreservation of equine spermatozoa, and comet assay is a valuable tool to monitor DNA cryo-damage in stallion sperm.

Keywords: Sodium Dodecyl sulfate, Egg yolk, Spermatozoa, Stallion.

\section{INTRODUCTION}

Cryopreservation of sperm is of great importance for the equine breeding industry, since it allows for long-term storage and transportation. Also cryopreserved semen increased the access to semen from stallions and insemination of mares at the optimal breeding time instead of relying on the availability of short-lived, cool-transported semen (Choi et al., 2002). A large part of the stallion population, however, remains unqualified for semen freezing programs because of unsatisfactory postthaw sperm quality and fertility rates (Loomis and Graham, 2008). Therefore, optimization of cryopreservation protocols for stallion sperm is an active field of research. Stallion semen is generally cryopreserved using a freezing extender that consists of skim milk, egg yolk and glycerol as cryoprotectants (Salazar et al., 2011). Over the years, various laboratories have tested and proposed various freezing extenders of various compositions in an attempt to improve the quality and use of frozen stallion semen (Loomis and Graham, 2008). Palmer (1984) proposed the use of a skim milk-egg yolkglycerol freezing extender supplemented with an assortment of sugars and electrolytes for cryopreservation of equine semen (termed INRA-82) which has higher fertility as compared with Kenney's extender (Ecot et al., 2001).

Glycerol has been the elective cryoprotectant used over the past 50 years for cryopreservation of stallion sperm (Alvarenga et al., 2005). Hoffmann et al. (2011) found that equine freezing extenders supplemented with glycerol showed the highest postthaw motility rates when used at concentrations of 2$3 \%$. Glycerol exerted toxicity at concentrations of $3.5 \%$ and the maximal toxicity was observed at $5 \%$ (García et al., 2012).

Hen egg yolk has been routinely used with success in freezing extenders for semen of many domestic animals including horses (Palmer, 1984) in a concentrations ranging from $2 \%$ to $22 \%$ (Khilfaoui et al., 2003; Hussain et al., 2011; Webb et al., 2011; Daigneault et al., 2012).

SDS in the form of Equex STM ${ }^{\circledR}$ and Orvus ES paste has been used as an additive to cryodiluents to enhance the protective effect of egg yolk by breaking 
down the lipid and making it more accessible to the sperm membrane (Pontbriand et al., 1989). SDS in the diluent has proved beneficial for the cryopreservation of sperm from a number of domestic and wildlife species (Holt, 2000).

Cryopreservation induces sublethal damage to the spermatozoa, which may result in loss of motility, viability, in vivo fertilizing capacity, deterioration of acrosomal and plasma membrane integrity, and damage of DNA (Coyan et al., 2012). Some authors suggest that sperm DNA integrity is a more objective marker of sperm function as opposed to the sperm parameters such as motility rates of fertilization, embryo cleavage, implantation, pregnancy, and live birth (Henkel et al., 2004; Agarwal and Allamaneni, 2004).

The aim of the present study was to demonstrate the effect of different concentrations of SDS, egg yolk and glycerol in the skim milk-based extender on the post-thaw semen characteristics in order to improve freezability and DNA integrity of stallion spermatozoa.

\section{MATERIALS and METHODS}

\section{Preparation of extender:}

INRA-82 extender was prepared by mixing equal amounts of glucose-saline solution and ultra-heat treated skim milk (Vidament et al., 2000). INRA-82 consists of: $25 \mathrm{~g} \backslash \mathrm{L}$ glucose monohydrate, $1.5 \mathrm{~g} \backslash \mathrm{L}$ lactose monohydrate, $1.5 \mathrm{~g} \backslash \mathrm{L}$ raffinose pentahydrate, $0.4 \mathrm{~g} \backslash \mathrm{L}$ potassium citrate monohydrate, $0.3 \mathrm{~g} \backslash \mathrm{L}$ sodium citrate dihydrate, 4.76 g HEPES, pH 7.0, 500 $\mathrm{mg} \backslash \mathrm{L}$ penicillin, $500 \mathrm{mg} \backslash \mathrm{L}$ gentamycin, and $0.15 \%$ skim milk. Aliquots of INRA-82 extenders were supplemented with different concentrations of SDS $(0.00,0.01,0.02,0.03$ and $0.04 \% \mathrm{w} / \mathrm{v})$, egg yolk $(5$, $10,15$ and $20 \% \mathrm{v} / \mathrm{v})$ and glycerol $(3,4,5,6$ and $7 \%$ $\mathrm{v} / \mathrm{v})$.

\section{Semen collection:}

On a once weekly collection schedule during the breeding season, three ejaculates per stallion were obtained from 7 Arabian stallions (7-12 years old) individually housed at a private farms in Cairo, Egypt. At time of collection, early in the morning, a mare in estrus was used as a mount animal. Semen was collected using a lubricated and pre-warmed (45 ${ }^{\circ} \mathrm{C}$ to $50{ }^{\circ} \mathrm{C}$ ) Colorado model artificial vagina with an inline filter to separate the gel fraction.

\section{Semen processing:}

Immediately following collection, the gel-free portion of the ejaculate was evaluated for volume and progressive motility, and concentration was determined with a hemocytometer. Only ejaculates with at least $60 \%$ progressively motile sperm and 250 x $10^{6}$ sperm cell $/ \mathrm{ml}$ were used for freezing. The semen was extended 1:1 (semen:extender) in INRA82 extender that had been warmed to $38^{\circ} \mathrm{C}$. The diluted samples were placed into $15-\mathrm{mL}$ tubes and centrifuged for 10 minutes at $400 \mathrm{~g}$. (Cochran et al., 1984). At least $95 \%$ of the supernatant was removed (Loomis, 2006) and each pellet was diluted with INRA-82 (in which different additives were added according to the experimental design) to a final sperm concentration of $100 \times 10^{6}$ motile sperm $/ \mathrm{ml}$. Each aliquot was cooled slowly to $5{ }^{\circ} \mathrm{C}$ over one hour under aerobic conditions, and then incubated at $5{ }^{\circ} \mathrm{C}$ for $30 \mathrm{~min}$ (Crockett et al., 2001). The extended semen was drawn into $0.5-\mathrm{mL}$ straws, sealed with a sealing powder and placed $4 \mathrm{~cm}$ above liquid nitrogen in the vapor phase in foam box for $10 \mathrm{~min}$ before being plunged into the liquid phase (Cristanelli et al., 1985). The straws were then stored in goblets on canes and kept immersed in liquid nitrogen. For thawing, two straws per treatment were warmed in a water bath at $38{ }^{\circ} \mathrm{C}$ for $30 \mathrm{sec}$. Individual motility was recorded just after thawing, 1, 2 and 3 hours postthawing. The post-thawing viability indices were estimated according to Milovanov (1962). Also, acrosomal integrity was estimated using fast green stain.

Hypo-osmotic swelling (HOS): The procedure described by Nie and Wenzel (2001) was used to determine the percentage of HOS positive cells in each sample. A $100 \mu \mathrm{l}$ aliquot of each semen sample was mixed in $1.0 \mathrm{ml}$ of a pre-warmed $100 \mathrm{mOsm}$ sucrose solution $(1.712 \mathrm{~g}$ sucrose dissolved in $50 \mathrm{ml}$ of sterile, de-ionized water). The mixture was incubated at $37^{\circ} \mathrm{C}$ for 60 minutes in a $1.5 \mathrm{ml}$ microcentrifuge tube. Following incubation, a small drop of sample was placed on a microscope slide and cover-slipped for examination by using phase contrast microscopy $(400 \mathrm{X})$ to evaluate 100 spermatozoa for evidence of swelling and curling changes. Also, acrosomal integrity was estimated using fast green stain (Wells and Awa, 1970).

Comet (Single cell gel electrophoresis assay): The alkaline comet assay for spermatozoa was carried out according to Hughes et al. (1996). Fully frosted glass slides were covered with $100 \mu \mathrm{l}$ of $0.5 \%$ normal melting point agarose (Sigma), a coverslip was added and the agarose was allowed to solidify. The coverslips were removed and $1 \times 10^{5}$ sperm cells in 50 $\mu \mathrm{l}$ PBS $(7.2 \mathrm{pH})$ were mixed with $50 \mu \mathrm{l}$ of $1.2 \%$ low melting point agarose and used to form the second layer. The slides with coverslips removed were then placed in lysis buffer for $1 \mathrm{~h}(2.5 \mathrm{M} \mathrm{NaCl}, 100 \mathrm{mM}$ Na EDTA, $10 \mathrm{mM}$ Tris, $1 \%$ Triton $\mathrm{X}$ at a $\mathrm{pH}$ of 10 ). The slides were then incubated at $37^{\circ} \mathrm{C}$ in $100 \mu \mathrm{l} / \mathrm{ml}$ of proteinase $\mathrm{K}$ in lysis buffer overnight. After draining the proteinase $\mathrm{K}$ solution from the slides, they were placed in a horizontal electrophoresis unit filled with freshly prepared alkaline electrophoresis solution containing $300 \mathrm{mM} \mathrm{NaOH}$ and $1 \mathrm{mM}$ EDTA 
for $20 \mathrm{~min}$ to allow the DNA to denature. Electrophoresis was performed at room temperature, at $25 \mathrm{~V}(0.714 \mathrm{~V} / \mathrm{cm})$ and $300 \mathrm{~mA}$, obtained by adjusting the buffer level, for $10 \mathrm{~min}$. The slides were then washed with a neutralizing solution of $0.4 \mathrm{M}$ Tris at $\mathrm{pH} 7$ to remove alkali and detergents. After neutralization, the slides were each stained with $50 \mu \mathrm{l}$ of $20 \mu \mathrm{g} / \mathrm{ml}$ ethidium bromide and mounted with a coverslip. A total of 200 sperm cells were examined under fluorescent microscope (400X). The intensity of the stain in the comet tail region is presumed to be related to the DNA content, and DNA damage is estimated from measurements of the percent DNA in tail, tail length and tail moment, using an image analysis system (Comet-Score program). Spermatozoa with fragmented DNA (damaged) display increased migration of the DNA from the nucleus towards the anode, while spermatozoa with non-fragmented DNA (undamaged) do not form a "comet" (Fraser, 2004).

\section{Statistical analysis:}

Two way analysis of variance and Duncan's multiple range tests were done for the obtained data after angular transformation of percentages to their corresponding arcsin values (Snedecor and Cochran, 1989). Data were analyzed using the 1984-version of Costat (Ecosoft, inc, USA), and $\mathrm{P}<0.05$ was considered as statistically significant.

\section{RESULTS}

As shown in Table 1, as compared to control $(0.00 \%$ SDS), SDS at a concentration of $0.03 \%$ had significantly $(\mathrm{P} \leq 0.01)$ improved sperm post thaw motility ( $48.75 \pm 4.73$ vs. $4.25 \pm 0.46$, respectively) and viability index $(123.10 \pm 11.29$ vs. $5.88 \pm 2.17$, respectively). The addition of SDS to semen extender at any concentration was found to exert no significant effect on sperm membranes and acrosomal integrities, percentage of sperm cells with non fragmented DNA, DNA in head and tail of comet, tail length and olive tail moment (Fig. 1).

Table 1: Effect of different concentrations of SDS on freezability, membranes, acrosomal and DNA integrities of stallion spermatozoa.

\begin{tabular}{|c|c|c|c|c|c|c|}
\hline & SDS conc. & $0.00 \%$ & $0.01 \%$ & $0.02 \%$ & $0.03 \%$ & $0.04 \%$ \\
\hline & Post-thawed (\%) & $\begin{array}{c}4.25 \\
\pm 0.46^{\mathrm{d}}\end{array}$ & $\begin{array}{r}14.25 \\
\pm 2.18^{c}\end{array}$ & $\begin{array}{c}42.50 \\
\pm 3.23^{\mathrm{ab}}\end{array}$ & $\begin{array}{r}48.75 \\
\pm 4.73^{\mathrm{a}}\end{array}$ & $\begin{array}{c}35.00 \\
\pm 3.54^{\mathrm{b}}\end{array}$ \\
\hline & $1^{\text {st }}$ hr. (\%) & $\begin{array}{c}2.25 \\
\pm 0.86^{\mathrm{c}}\end{array}$ & $\begin{array}{c}10.00 \\
\pm 2.04^{\mathrm{c}}\end{array}$ & $\begin{array}{c}32.50 \\
\pm 3.23^{\mathrm{ab}}\end{array}$ & $\begin{array}{c}40.00 \\
\pm 3.54^{\mathrm{a}}\end{array}$ & $\begin{array}{l}28.75 \\
\pm 3.15\end{array}$ \\
\hline & $2^{\text {nd }}$ hr. (\%) & $\begin{aligned} & 1.25 \\
\pm & 0.75^{\mathrm{c}}\end{aligned}$ & $\begin{aligned} & 7.50 \\
\pm & 1.04^{\mathrm{c}}\end{aligned}$ & $\begin{array}{c}26.25 \\
\pm 4.27^{\mathrm{ab}}\end{array}$ & $\begin{array}{c}32.50 \\
\pm 3.23^{\mathrm{a}}\end{array}$ & $\begin{aligned} & 22.50 \\
\pm & 5.00^{\mathrm{b}}\end{aligned}$ \\
\hline & $3^{\text {rd }}$ hr. $(\%)$ & $\begin{aligned} & 0.25 \\
\pm & 0.25^{\mathrm{c}}\end{aligned}$ & $\begin{aligned} & 4.25 \\
\pm & 1.50^{c}\end{aligned}$ & $\begin{array}{l}17.50 \\
\pm 3.23^{\mathrm{b}}\end{array}$ & $\begin{array}{r}26.25 \\
\pm 2.40^{\mathrm{a}}\end{array}$ & $\begin{aligned} & 16.25 \\
\pm & 2.40^{\mathrm{b}}\end{aligned}$ \\
\hline & Viability index & $\begin{array}{c}5.88 \\
\pm 2.17^{\mathrm{c}}\end{array}$ & $\begin{array}{c}28.88 \\
\pm 11.08^{c}\end{array}$ & $\begin{array}{c}97.50 \\
\pm 12.29^{\mathrm{ab}}\end{array}$ & $\begin{array}{c}123.10 \\
\pm 11.29^{\mathrm{a}}\end{array}$ & $\begin{array}{c}85.00 \\
\pm 9.91^{b}\end{array}$ \\
\hline & OS positive sperm (\%) & $\begin{array}{c}31.75 \\
\pm 1.11^{\mathrm{a}}\end{array}$ & $\begin{array}{c}31.75 \\
\pm 1.70^{\mathrm{a}}\end{array}$ & $\begin{array}{c}35.25 \\
\pm 2.63^{\mathrm{a}}\end{array}$ & $\begin{array}{c}38.25 \\
\pm 2.18^{\mathrm{a}}\end{array}$ & $\begin{array}{c}37.50 \\
\pm 2.50^{\mathrm{a}}\end{array}$ \\
\hline & rosomal integrity (\%) & $\begin{array}{c}29.00 \\
\pm 1.52^{\mathrm{a}}\end{array}$ & $\begin{array}{r}28.75 \\
\pm 1.32^{\mathrm{a}}\end{array}$ & $\begin{array}{c}31.00 \\
\pm 2.16^{\mathrm{a}}\end{array}$ & $\begin{array}{c}32.75 \\
\pm 1.32^{\mathrm{a}}\end{array}$ & $\begin{array}{c}31.00 \\
\pm 1.08^{\mathrm{a}}\end{array}$ \\
\hline & $\begin{array}{c}\text { Sperm with non- } \\
\text { fragmented DNA }(\%)\end{array}$ & $\begin{array}{l}94.75 \\
\pm 1.44^{\mathrm{a}}\end{array}$ & $\begin{array}{r}91.75 \\
\pm 1.15^{\mathrm{a}}\end{array}$ & $\begin{array}{r}96.50 \\
\pm 0.95^{\mathrm{a}}\end{array}$ & $\begin{array}{r}92.00 \\
\pm 1.83^{\mathrm{a}}\end{array}$ & $\begin{array}{r}92.25 \\
\pm 1.19^{\mathrm{a}}\end{array}$ \\
\hline$\vec{g}$ & $\begin{array}{c}\text { DNA in head of comet } \\
(\%)\end{array}$ & $\begin{array}{r}99.19 \\
\pm 0.50^{\mathrm{a}}\end{array}$ & $\begin{array}{r}97.93 \\
\pm 0.91^{\mathrm{a}}\end{array}$ & $\begin{array}{r}98.58 \\
\pm 0.40^{\mathrm{a}}\end{array}$ & $\begin{array}{l}98.64 \\
\pm 0.30^{\mathrm{a}}\end{array}$ & $\begin{array}{r}98.25 \\
\pm 0.69^{\mathrm{a}}\end{array}$ \\
\hline 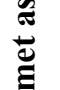 & $\begin{array}{c}\text { DNA in tail of comet } \\
(\%)\end{array}$ & $\begin{aligned} & 0.81 \\
\pm & 0.50^{\mathrm{a}}\end{aligned}$ & $\begin{aligned} & 2.07 \\
\pm & 0.91^{\mathrm{a}}\end{aligned}$ & $\begin{aligned} & 1.42 \\
\pm & 0.40^{\mathrm{a}}\end{aligned}$ & $\begin{aligned} & 1.36 \\
\pm & 0.30^{\mathrm{a}}\end{aligned}$ & $\begin{aligned} & 1.75 \\
\pm & 0.69^{\mathrm{a}}\end{aligned}$ \\
\hline$\dot{U}$ & Tail length (pixel) & $\begin{array}{r}10.75 \\
\pm 1.18^{\mathrm{a}}\end{array}$ & $\begin{array}{c}10.75 \\
\pm 1.70^{\mathrm{a}}\end{array}$ & $\begin{array}{c}11.00 \\
\pm 1.35^{\mathrm{a}}\end{array}$ & $\begin{array}{c}9.00 \\
\pm 0.82^{\mathrm{a}}\end{array}$ & $\begin{array}{c}7.00 \\
\pm 1.58^{\mathrm{a}}\end{array}$ \\
\hline & Olive tail moment & $\begin{array}{c}0.16 \\
\pm 0.07^{\mathrm{a}}\end{array}$ & $\begin{array}{c}0.68 \\
\pm 0.40^{\mathrm{a}}\end{array}$ & $\begin{array}{c}0.22 \\
\pm 0.05^{\mathrm{a}}\end{array}$ & $\begin{array}{c}0.20 \\
\pm 0.02^{\mathrm{a}}\end{array}$ & $\begin{array}{c}0.57 \\
\pm 0.42^{\mathrm{a}}\end{array}$ \\
\hline
\end{tabular}

As presented in Table 2 , the addition of $15 \%$ egg yolk to the INRA- 82 extender resulted in the highest $(\mathrm{P} \leq 0.001)$ sperm post-thaw motility $(50.00 \pm 2.04 \%)$, viability index $(130.00 \pm 7.43)$, sperm membranes, acrosomal and DNA integrities $(38.00 \pm 0.73 \%, 33.00 \pm 0.92 \%$ and $95.25 \pm 0.48 \%$, respectively). On the other hand, the addition of $5 \%$ egg yolk resulted in the lowest $(\mathrm{P} \leq 0.001)$ sperm post-thaw motility, viability index, sperm membranes, acrosomal and DNA integrities $(27.50 \pm$ $3.23 \%, 60.00 \pm 8.72,27.50 \pm 1.04,25.50 \pm 1.04$ and $84.75 \pm 0.85 \%$, respectively). The addition of egg yolk to semen extender at any concentration was found to exert no significant effect on DNA in head and tail of comet, tail length and olive tail moment (Fig. 1). 
Table 2: Effect of different concentrations of egg yolk on freezability, membranes, acrosomal and DNA integrities of stallion spermatozoa.

\begin{tabular}{|c|c|c|c|c|}
\hline Egg yolk conc. & $5 \%$ & $10 \%$ & $15 \%$ & $20 \%$ \\
\hline Post-thawed (\%) & $27.50 \pm 3.23^{c}$ & $35.00 \pm 3.54^{b c}$ & $50.00 \pm 2.04^{\mathrm{a}}$ & $43.75 \pm 3.15^{\mathrm{ab}}$ \\
\hline $1^{\text {st }}$ hr. $(\%)$ & $21.25 \pm 3.15^{b}$ & $30.00 \pm 3.54^{\mathrm{ab}}$ & $41.25 \pm 2.40^{\mathrm{a}}$ & $38.75 \pm 3.15^{\mathrm{a}}$ \\
\hline $2^{\text {nd }}$ hr. (\%) & $15.00 \pm 2.04^{\mathrm{c}}$ & $26.25 \pm 2.39^{b}$ & $35.00 \pm 2.04^{\mathrm{a}}$ & $31.25 \pm 2.39^{\mathrm{ab}}$ \\
\hline $3^{\text {rd }}$ hr. $(\%)$ & $10.00 \pm 2.04^{\mathrm{c}}$ & $20.00 \pm 2.04^{b}$ & $28.75 \pm 2.39^{\mathrm{a}}$ & $26.25 \pm 2.40^{\mathrm{ab}}$ \\
\hline Viability index & $60.00 \pm 8.72^{c}$ & $93.75 \pm 9.49^{b}$ & $130.00 \pm 7.43^{\mathrm{a}}$ & $118.13 \pm 9.27^{\mathrm{ab}}$ \\
\hline HOS positive sperm (\%) & $27.50 \pm 1.04^{\mathrm{c}}$ & $32.75 \pm 0.63^{b}$ & $38.00 \pm 0.73^{\mathrm{a}}$ & $37.00 \pm 1.47^{\mathrm{a}}$ \\
\hline Acrosomal integrity (\%) & $25.50 \pm 1.04^{\mathrm{b}}$ & $29.50 \pm 0.65^{\mathrm{a}}$ & $33.00 \pm 0.92^{\mathrm{a}}$ & $31.00 \pm 1.08^{\mathrm{a}}$ \\
\hline $\begin{array}{c}\text { Sperm with non- } \\
\text { fragmented DNA }(\%)\end{array}$ & $84.75 \pm 0.85^{c}$ & $92.25 \pm 1.11^{\mathrm{b}}$ & $95.25 \pm 0.48^{\mathrm{a}}$ & $96.25 \pm 0.75^{\mathrm{a}}$ \\
\hline $\begin{array}{c}\text { DNA in head of comet } \\
(\%)\end{array}$ & $95.16 \pm 1.94^{\mathrm{a}}$ & $98.13 \pm 0.65^{\mathrm{a}}$ & $99.53 \pm 0.08^{\mathrm{a}}$ & $98.40 \pm 0.76^{\mathrm{a}}$ \\
\hline $\begin{array}{l}\text { DNA in tail of comet } \\
(\%)\end{array}$ & $4.84 \pm 1.94^{\mathrm{a}}$ & $1.87 \pm 0.65^{\mathrm{a}}$ & $0.47 \pm 0.08^{\mathrm{a}}$ & $1.60 \pm 0.76^{\mathrm{a}}$ \\
\hline Tail length (pixel) & $16.00 \pm 4.98^{\mathrm{a}}$ & $11.00 \pm 1.47^{\mathrm{a}}$ & $10.00 \pm 1.29^{\mathrm{a}}$ & $5.50 \pm 1.04^{\mathrm{a}}$ \\
\hline Olive tail moment & $0.99 \pm 0.62^{\mathrm{a}}$ & $0.21 \pm 0.08^{a}$ & $0.10 \pm 0.05^{\mathrm{a}}$ & $0.55 \pm 0.42^{\mathrm{a}}$ \\
\hline
\end{tabular}

Regarding the effect of different concentrations of egg yolk on freezability, membranes, acrosomal and DNA integrities of stallion spermatozoa (Table 3), the addition of $5 \%$ glycerol to the freezing extender resulted in the highest $(\mathrm{P} \leq 0.001)$ sperm post-thaw motility, viability index, sperm membranes and acrosomal integrities $(50.00$ $\pm 3.54 \%, 126.25 \pm 11.21,38.75 \pm 1.32 \%$ and $32.25 \pm 1.11 \%$, respectively). With the increase in the percentage of glycerol added to the extender, there was dose dependent decrease in the percentage of sperm non-fragmented DNA and the percentage of DNA in tail of the comet, while there was dose dependent increase in the percentage of DNA in tail of comet, comet tail length and Olive tail moment (Fig. 2). 
Table 3: Effect of different concentrations of glycerol on freezability, membranes, acrosomal and DNA integrities of stallion spermatozoa.

\begin{tabular}{|c|c|c|c|c|c|}
\hline Glycerol conc. & $3 \%$ & $4 \%$ & $5 \%$ & $6 \%$ & $7 \%$ \\
\hline \multirow[t]{2}{*}{ Post-thawed (\%) } & 33.75 & 43.75 & 50.00 & 33.75 & 28.75 \\
\hline & $\pm 4.73^{\mathrm{ab}}$ & $\pm 4.73^{\mathrm{ab}}$ & $\pm 3.54^{\mathrm{a}}$ & $\pm 4.73^{\mathrm{ab}}$ & $\pm 4.73^{b}$ \\
\hline \multirow[t]{2}{*}{$1^{\text {st }}$ hr. (\%) } & 27.50 & 37.50 & 40.00 & 27.50 & 23.75 \\
\hline & $\pm 4.33^{\mathrm{a}}$ & $\pm 4.33^{\mathrm{a}}$ & $\pm 3.54^{\mathrm{a}}$ & $\pm 4.33^{\mathrm{a}}$ & $\pm 4.73^{\mathrm{a}}$ \\
\hline \multirow[t]{2}{*}{$2^{\text {nd }}$ hr. $(\%)$} & 20.00 & 30.00 & 33.75 & 21.25 & 17.5 \\
\hline & $\pm 3.54^{\mathrm{a}}$ & $\pm 3.54^{\mathrm{a}}$ & $\pm 3.15^{\mathrm{a}}$ & $\pm 4.47^{\mathrm{a}}$ & $\pm 4.33^{\mathrm{a}}$ \\
\hline \multirow[t]{2}{*}{$3^{\text {rd }}$ hr. $(\%)$} & 15.00 & 22.50 & 27.50 & 15.00 & 13.75 \\
\hline & $\pm 3.54^{b}$ & $\pm 2.50^{\mathrm{ab}}$ & $\pm 3.23^{\mathrm{a}}$ & $\pm 2.04^{b}$ & $\pm 3.15^{b}$ \\
\hline \multirow[t]{2}{*}{ Viability index } & 79.38 & 111.88 & 126.25 & 80.63 & 69.38 \\
\hline & $\pm 13.63^{\mathrm{ab}}$ & $\pm 12.56^{\mathrm{ab}}$ & $\pm 11.21^{\mathrm{a}}$ & $\pm 12.77^{\mathrm{ab}}$ & $\pm 14.41^{b}$ \\
\hline \multirow[t]{2}{*}{ HOS positive sperm (\%) } & 32.50 & 34.25 & 38.75 & 34.50 & 31.00 \\
\hline & $\pm 1.56^{\mathrm{b}}$ & $\pm 1.38^{\mathrm{ab}}$ & $\pm 1.32^{\mathrm{a}}$ & $\pm 1.04^{\mathrm{ab}}$ & $\pm 1.08^{b}$ \\
\hline \multirow[t]{2}{*}{ Acrosomal integrity (\%) } & 25.50 & 28.75 & 32.25 & 30.00 & 26.00 \\
\hline & $\pm 0.56^{\mathrm{b}}$ & $\pm 1.65^{\mathrm{ab}}$ & $\pm 1.11^{\mathrm{a}}$ & $\pm 1.08^{\mathrm{ab}}$ & $\pm 1.42^{b}$ \\
\hline \multirow{10}{*}{$\begin{array}{l}\text { Sperm with non- } \\
\text { fragmented DNA } \\
(\%)\end{array}$} & 95.00 & 93.00 & 87.25 & 79.75 & 75.75 \\
\hline & $\pm 0.91^{\mathrm{a}}$ & $\pm 0.91^{\mathrm{a}}$ & $\pm 0.85^{\mathrm{b}}$ & $\pm 0.85^{\mathrm{c}}$ & $\pm 0.85^{\mathrm{d}}$ \\
\hline & 99.11 & 98.35 & 95.96 & 93.41 & 91.26 \\
\hline & $\pm 0.42^{\mathrm{a}}$ & $\pm 0.73^{\mathrm{a}}$ & $\pm 0.88^{b}$ & $\pm 0.93^{c}$ & $\pm 0.71^{\mathrm{c}}$ \\
\hline & 0.89 & 1.65 & 4.04 & 6.59 & 8.74 \\
\hline & $\pm 0.42^{\mathrm{c}}$ & $\pm 0.73^{\mathrm{c}}$ & $\pm 0.88^{b}$ & $\pm 0.93^{\mathrm{a}}$ & $\pm 0.71^{\mathrm{a}}$ \\
\hline & 7.50 & 8.50 & 13.00 & 12.50 & 18.50 \\
\hline & $\pm 1.44^{\mathrm{b}}$ & $\pm 0.95^{\mathrm{b}}$ & $\pm 1.68^{b}$ & $\pm 1.04^{b}$ & $\pm 1.50^{\mathrm{a}}$ \\
\hline & 0.11 & 0.24 & 0.59 & 0.82 & 2.16 \\
\hline & $\pm 0.04^{\mathrm{c}}$ & $\pm 0.08^{b c}$ & $\pm 0.19^{b c}$ & $\pm 0.84^{\mathrm{b}}$ & $\pm 1.08^{\mathrm{a}}$ \\
\hline
\end{tabular}

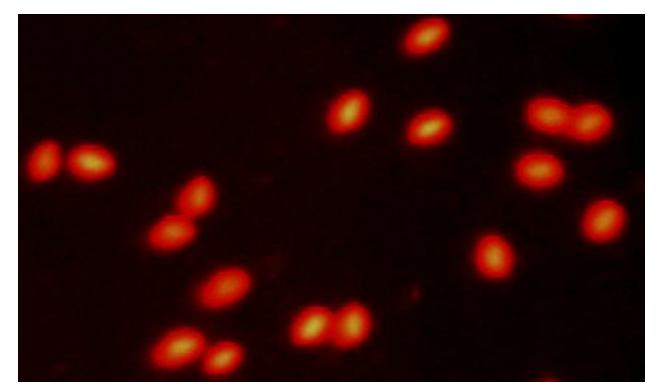

Fig.1: Sperm cells with intact, undamaged comet picture of stallion spermatozoa (with no DNA fragmentation).

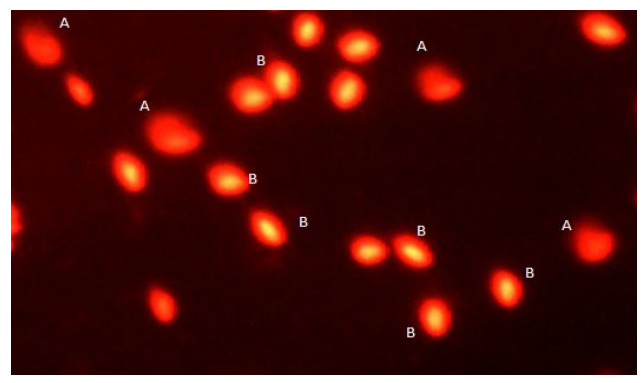

Fig.2: Comet picture of stallion spermatozoa with (A) or without (B) no DNA fragmentation. 


\section{DISCUSSION}

In the current work, SDS was found to be fundamental for cryopreservation of stallion spermatozoa and the ideal concentration of SDS in INRA-82 extender was $0.03 \%$. Similarly, $0.035 \%$ SDS preserved the motility and fertilization capacity of mouse spermatozoa (Dewit et al., 2000). High concentrations of SDS were found to have a detrimental effect on both motility and acrosome integrity of frozen-thawed goat spermatozoa (Aboagla and Terada, 2004). The integrity of mouse spermatozoa was significantly reduced when $>0.05 \%$ SDS was incorporated into the extender (Dewit et al., 2000) as when SDS is used at a high concentration in the extender, free SDS molecules increased and may bind directly to the sperm membrane, with devastating results. The addition of different amounts of SDS or SDS-containing compounds (Equex STM paste or Orvus ES paste) to extenders for freezing of semen has been found beneficial in stallion (Martin et al., 1979), enhancing motility (Purse et al., 1978; Martin et al., 1979; Arriola and Foote, 1987) and acrosome integrity (Arriola and Foote, 1987) and giving high fertilization rates both in vivo (Arriola and Foote, 1987; Linde-Forsberg, 1991) and in vitro (Penfold and Moore, 1993). The precise mechanisms by which SDS improves sperm cryosurvival remain unknown. However, it has been demonstrated that SDS is only beneficial in the presence of egg yolk, suggesting that it functions by altering the tertiary structure of the egg yolk lipoproteins (Purse et al., 1978). SDS improves the post-thaw survival of spermatozoa by acting as a surfactant to stabilize cell membranes, particularly acrosomal membranes, and to protect spermatozoa against the toxic effects of glycerol during the freeze-thaw process (Martin et al., 1979; Arriola and Foote, 1987).

The addition of SDS to semen extender under present study was found to exert no significant effect on sperm membranes and acrosomal integrities. Similarly, in Sika deer spermatozoa, Cheng et al. (2004) found that SDS did not affect the sperm acrosomal morphology. In contrast, addition of SDS to the freezing extender significantly improves canine sperm membrane integrity (Rota et al., 1997; Peña and Linde-Forsberg, 2000) and acrosomal integrity (Arriola and Foote, 1987).

Egg yolk (depends on containing cholesterol, phospholipids, and low-density lipoprotein) prevents the formation of ice crystal, thus protecting integrity of sperm plasma membranes against cold shock during the freeze-thaw process ( $\mathrm{Hu}$ et al., 2010). Based on our results, the addition of $15 \%$ egg yolk to the INRA-82 extender resulted in the highest sperm post-thaw motility, viability index, sperm membranes, acrosomal and DNA integrities. The concentration of egg yolk varies strongly in the equine freezing extenders: $2.0 \%$ (Vidament et al., 2000; Khlifaoui et al., 2003), 4.0\% (Jasko et al., 1992), 5.0\% (Madison et al., 2013), 10\% (Squires et al., 2004), 20.0\% (Cristanelli et al., 1985; Hussain et al., 2011; Salazar et al., 2011). However, these apparent differences in the egg yolk concentration may be due to different breeds, spermatozoa concentration, kind of extender, the ratio of extender, and other compositions of extender.

Our results pointed out that, there was no benefit to increasing the concentration of egg yolk above $15 \%$ in INRA-82 extender. This is in contrast to previous reports, which stated that there was no difference in results when $16 \%$ versus $20 \%$ egg yolk were used as components of a lactose EDTA diluent (Cristanelli et al., 1985). Earlier report of Pickett et al. (1975) stated that the high concentration of egg yolk in the extender may have also contributed to a reduction in fertility.

Glycerol is the permeating cryoprotectant most frequently used to freeze semen from different species (Baren et al., 2004). The addition of 5\% glycerol to the freezing extender in the current study resulted in the highest sperm post-thaw motility, viability index, sperm membranes and acrosomal integrities. Meanwhile, increasing the concentration of glycerol above $5 \%$ resulted in toxic effect on the sperm DNA integrity presented as decreased percentage of sperm non-fragmented DNA and the percentage of DNA in tail of the comet and increased percentage of DNA in tail of comet, comet tail length and Olive tail moment. The ability to detect sublethal, and possibly uncompensable, fertility factors in stallion sperm, such as DNA fragmentation, could add yet another parameter to monitor and preserve optimal fertility on an individual basis (Linfor and Meyers, 2002). A variety of methods have been developed for detecting DNA strand damage (Benchaib et al., 2003; Charles, 2005). The comet assay has proven to be a very sensitive method for detecting DNA strand breaks in human sperm (Duty et al., 2002). The comet assay parameters, tail length and tail moment, provide additional evidence about the level of DNA damage sustained by frozen-thawed sperm cells, and therefore increase the sensitivity of the comet assay in detecting low levels of DNA damage (Fraser and Strzezek, 2007). Comet assay is capable of detecting DNA damage in stallion sperm from ejaculates subjected to low-temperature storage (Linfor and Meyers, 2002). Based on our results, high concentrations of glycerol had been shown to be deleterious to DNA of sperm cells subjected to cryopreservation, as increasing the glycerol level from $5 \%$ to $7 \%$ resulted in increase of DNA fragmentation, DNA in comet tail, comet tail length and Olive tail moment by; $11.5 \%, 4.7 \%, 5.5$ pixels and 1.57, respectively. Similarly, Baumber et al. (2003) found that cryopreservation of equine 
spermatozoa caused a marked increase in DNA fragmentation measured by the comet assay. In bull, Słowinska et al. (2008) reported that cryopreservation caused a low (3.8\%) decrease in the percentage of DNA in the comet head and an increase $(5.3 \%)$ in the tail length.

Based on this study, it was concluded that the addition of appropriate concentration of SDS is fundamental for equine semen cryopreservation, $0.03 \%$ SDS, $15 \%$ egg yolk and 5\% glycerol are the optimum concentrations for cryopreservation of equine spermatozoa with minimal detrimental effects, and comet assay is a valuable tool to monitor DNA cryo-damage in stallion sperm.

\section{REFERENCES}

Aboagla, E.M. and Terada, T. (2004): Effects of the supplementation of trehalose extender containing egg yolk with sodium dodecyl sulfate on the freezability of goat spermatozoa. Theriogenology, 62: 809-818

Agarwal, A. and Allamaneni, S.S. (2004): The effect of sperm DNA damage on assisted reproduction outcomes. A review. Minerva Ginecol., 56:235-245.

Alvarenga, M.A.; Papa, F.O.; Landim-Alvarenga, F.C. and Medeiros, A.S.L. (2005): Amides as cryoprotectant for freezing stallion semen: a review. Anim. Reprod. Sci., 89: 105-113.

Arriola, J. and Foote, R.H. (1987): Glycerolation and thawing effects on bull spermatozoa frozen in detergent-treated egg yolk and whole egg extenders. J. Dairy Sci., 70: 1664-1670.

Baren, A.; Bacinoglu, S.; Evecen, M.; Sahin, B.E.; Alkan, S.; Demir, K.; Ak, K. and Ileri, K. (2004): Freezing of cat semen in straws with different GLY levels containing Tris-extender. Turk. J. Vet. Anim. Sci., 28: 545-552.

Barker, C.A.V. and Gandier, J.C. (1957): Pregnancy in a mare resulted from frozen epididymal spermatozoa. Can. J. Comp. Med. Vet. Sci., 21: 47-51.

Baumber, J.; Ball, B.A.; Linfor, J.J. and Meyers, S.A. (2003): Reactive oxygen species and cryopreservation promote DNA fragmentation in equine spermatozoa, J. Androl., 24: 621-628.

Benchaib, M.; Valerie, B.; Jacqueline, L.; Samia, H.; Bruno, S.; Herve, L.; Jean, F. and Guerin, S. (2003): DNA fragmentation decreases the pregnancy rate in an assisted reproductive technique. Hum. Reprod., 18: 1023-1028.

Charles, C.L. (2005): The sperm chromatin structure assay: a review of clinical applications. Anim. Reprod. Sci. 89: 39-45.

Cheng, F.; Wu, J.; Chan, J.; Wang, J.; Fung, H. and Colenbrander, B. and Tung, K. (2004): The effect of different extenders on post-thaw sperm survival, acrosomal integrity and longevity in cryopreserved semen of Formosan Sika deer and Formosan Sambar deer. Theriogenology, 61: 1605-1616.

Choi, Y.H.; Love, C.C.; Love, L.B.; Varner, D.; Brinsko, S.P. and Hinrichs, K. (2002): Developmental competence on vivo and in vitro of in vitro matured equine oocytes fertilized by intracytoplasmic sperm injection with fresh or frozen-thawed sperm. Reprod., 123: 455-4 65 .

Cochran, J.D.; Amann, R.P.; Froman, D.P. and Pickett, B.W. (1984): Effects of centrifugation, glycerol level, cooling to $5 \mathrm{C}$, freezing rate and thawing rate on the post-thaw motility of equine sperm. Theriogenology, 22:25-38.

Costat Computer Program copyright (1986): version 3.03 copyright software.

Coyan, K.; Bucak, M.N.; Bas, N.; Tas, P.M. and Aydos, P. (2012): Ergothioneine attenuates the DNA damage of post-thawed Merino ram sperm. Small Rum. Res., 106: 165-167.

Cristanelli, M.J.; Amann, R.P.; Squires, E.L. and Pickett, B.W. (1985): Effects of egg yolk and glycerol level in lactose-EDTA-egg yolk extender and of freezing rate on the motility of frozen-thawed stallion spermatozoa. Theriogenology, 23: 25-38.

Crockett, E.C.; Graham, J.K.; Bruemmer, J.E. and Squires, E.L. (2001): Effect of cooling of equine spermatozoa before freezing on postthaw motility: preliminary results. Theriogenology, 55: 793-803.

Daigneault, B.W.; Graham, J.K.; Bruemmer, J.E.; Denniston, D.J. and Carnevale, E.M. (2012): Cryopreservation of cooled semen and evaluation of sperm holding media for potential use in equine-assisted reproduction procedures. J. Equi. Vet. Sci., 32: 569-574.

Dewit, M.; Marley, M.S. and Graham, J.K. (2000): Fertilizing potential of mouse spermatozoa cryopreserved in a medium containing whole eggs. Cryobiology, 40: 36-45.

Dobrinski, I.; Thomas, P.G. and Ball, B.A. (1995): Cryopreservation reduces the ability of equine spermatozoa to attach to oviductal epithelial cells and zonae pellucidae in vitro. J. Androl., 16:536-542.

Duty, S.M.; Singh, N.P.; Ryan, L.; Chen, Z.; Lewis, C.; Huang, T. and Hauser, R. (2002): Reliability of the comet assay in cryopreserved human sperm. Reliability of the comet assay in cryopreserved human sperm. Hum. Reprod., 17: 1274-1280.

Ecot, P.; Arnaud, G.; Moy, A.; Daels, P.; Magistrini, M. and Vidament, M. (2001): Comparison of fertility and post-thaw semen criteria of stallion semen frozen in two different extenders. Anim. Reprod. Sci., 68: 356-8.

Fayrer-Hosken, R.; Abreu-Barbosa, C.; Heusner, G. and Jones, L. (2008): Cryopreservation of 
Stallion Spermatozoa with INRA96 and Glycerol. J. Equi. Vet. Sci., 28: 672-677.

Fraser, L. (2004): Structural damage to nuclear DNA in mammalian spermatozoa: its evaluation techniques and relationship with male infertility. Polish J. Vet. Sci., 7: 311-321.

Fraser, L. and Strzezek, J. (2007): Effect of different procedures of ejaculate collection, extenders and packages on DNA integrity of boar spermatozoa following freezing-thawing, Anim. Reprod. Sci., 99: 317-329.

García, B.M.; Ferrusola, C.O.; Aparicio, I.M.; MiróMorán, A.; Rodriguez, A.; Bolaños, J.M.; Fernández, L.; Balao, C.M.; Martínez, H.; Tapia, J.A. and Peña, F.J. (2012): Toxicity of glycerol for the stallion spermatozoa: Effects on membrane integrity and cytoskeleton, lipid peroxidation and mitochondrial membrane potential. Theriogenology, 77: 1280-1289.

Hammerstedt, R.H., Graham, J.K. and Nolan, J.P. (1990): Cryopreservation of mammalian sperm: what we ask them to survive. J. Androl., 11: 73-88.

Henkel, R.; Hajimohammad, M.; Stalf, T; Hoogendijk, C.; Mehnert, C. and Menkveld, R. (2004): Influence of deoxyribonucleic acid damage on fertilization and pregnancy. Fertil. Steril., 81: 965-972.

Hoffmann, N.; Oldenhof, H.; Morandini, C.; Rohn, K. and Sieme, H. (2011): Optimal concentrations of cryoprotective agents for semen fromstallions that are classified 'good' or 'poor' for freezing. Anim. Reprod. Sci., 125: 112-118.

Holt, W.V. (2000): 'Basic aspects of frozen storage of semen', Anim. Reprod. Sci., 62: 3-22.

Hu, J.H.; Li, Q.W.; Zan, L.S.; Jiang, Z.L.; An, J.H. and Wang, L.Q. (2010): The cryoprotective effect of low-density lipoproteins in extenders on bull spermatozoa following freezingthawing. Anim. Reprod. Sci., 117:11-17.

Hughes, C.M.; Lewis, S.E.; McKelvey-Martin, V. and Thompson, W.A. (1996): comparison of baseline and induced DNA damage in human spermatozoa from fertile and infertile men, using a modified comet assay. Mol. Hum. Reprod., 2: 613-619.

Hussain, J.; Abdul Salam, A. and Gohar, A. (2011): A Study on the Cryopreservation of Stallion Semen with Alpha Lipoic Acid. Intl. R. J. of Pharmaceuticals, 1 (1): 21-26.

Jasko, D.J.; Hathaway, J.A.; Schaltenbrand, V.L.; Simper, W.D. and Squires, E.L. (1992): Effect of seminal plasma and egg yolk on motion characteristics of cooled stallion spermatozoa. Theriogenology, 37:1241-1252.

Khilfaoui, M.; Battut, I.; Jean, M.; Bruyas, J.F.; Thorin, C. and Tainturier, D. (2003): Assessment of fertilizing ability of frozen- thawed semen in glutamine extender. J. Anim \& Vet. Advances, 2: 686-692.

Linde-Forsberg, C. (1991): Achieving canine pregnancy using frozen or chilled extended semen. Veterinary Clinics of North America: Small Animal Practice, 21: 467-485.

Linfor, J.J. and Meyers, S.A. (2002): Detection of dna damage in response to cooling injury in equine spermatozoa using single-cell gel electrophoresis. J. Androl., 23: 107-113.

Loomis, P.R. (2006): Advanced methods for handling and preparation of stallion semen. Vet. Clin. North Am. Equine. Pract.; 22: 663-676.

Loomis, P.R. and Graham, J.K. (2008): Commercial semen freezing: individual male variation in cryosurvival and the response of stallion sperm to customized freezing protocols. Anim. Reprod. Sci., 105: 119-128.

Madison, R.J.; Evans, L.E. and Youngs, C.R. (2013): The effect of 2-hydroxypropyl-b-cyclodextrin on post-thaw parameters of cryopreserved jack and stallion semen. J. Equi. Vet. Sci., 33: 272-278.

Martin, J.C.; Klug, E. and Gunzel, A.R. (1979): Centrifugation of stallion semen and its storage in large volume straws. J. Reprod. Fertil., 27 (Suppl): 47-51.

Milovanov, V.K. (1962): Biology of Reproduction and Artificial Insemination of Farm Animals. Monograph. Selkohz. Lit. J. and Plakatov, Moscow.

Moffet, P.D.; Bruemmer, J.E.; Card, C. and Squires, E.L. (2003): Comparison of dimethyl formamide and glycerol for cryopreservation of equine spermatozoa. In: Proceedings Society for Theriogenology Annual Conference, 2003, Columbus, OH. Montgomery, AL: pp. 42 (abst.).

Moore, A.I.; Squires, E.L.; Bruemmer, J.E. and Graham, J.K. (2006): Effect of cooling rate and cryoprotectant on the cryosurvival of equine spermatozoa. J. Equi. Vet. Sci., 26: 215-219.

Nie, G.J. and Wenzel, J.G.W. (2001): Adaptation of the hypo-osmotic swelling test to assess functional integrity of stallion spermatozoal plasma membranes. Theriogenology, 55: 1005-1018.

Palmer, E. (1984): Factors affecting stallion semen survival and fertility.10th Int. Cong. on Anim. Reprod. and A.I., June 10-14 1984, University of Illinois, USA Vol. III, pp. 3.

Peña, A. and Linde-Forsberg, C. (2000): Effects of Equex, one- or two-step dilution, and two freezing and thawing rates on post-thaw survival of dog spermatozoa. Theriogenology, 54: 859-875.

Penfold, L.M. and Moore, H.D. (1993): A new method for cryopreservation of mouse spermatozoa. J. Reprod. Fertil., 99: 131-134. 
Pickett, B.W.; Burwash, L.D.; Voss, J.L. and Back, D.G. (1975): Effect of seminal extenders on equine fertility. J. Anim. Sci., 40: 1136-1143.

Pontbriand, D.; Howard, J.; Schieve, M.C.; Stuart, L.D. and Wildt, D.E. (1989): 'Effect of cryoprotective diluent and method of freezethawing on survival and acrosomal integrity of ram spermatozoa', Cryobiology, 26: 341-354.

Purse, V.G.; Schulman, L.L. and Johnson, LA. (1978): Effect of Orvus ES paste on acrosome morphology, motility and fertilizing capacity of frozen-thawed boar sperm. J. Anim. Sci., 47: 198-202.

Rota, A.; Strom, B.; Linde-Forsberg, C. and Rodriguez-Martinez, H. (1997): Effects of Equex STM Paste on viability of frozenthawed dog spermatozoa during in vitro incubation at $38^{\circ} \mathrm{C}$. Theriogenology, 47: 1093-1101.

Salazar, J.L.; Teague, S.R.; Love, C.C.; Brinsko, S.P.; Blanchard, T.L. and Varner, D.D. (2011): Effect of cryopreservation protocol on postthaw characteristics of stallion sperm. Theriogenology, 76: 409-418.

Stowinska, M.; Karol, H. and Ciereszko, A. (2008): Comet assay of fresh and cryopreserved bull spermatozoa. Cryobiology, 56: 100-102.

Snedecor, G.W. and Cochran, W.G. (1989): Statistical Methods. $8^{\text {th }}$ Ed. Iowa State Univ. Press, Ames, IA, USA.

Squires, E.L.; Keith, S.L. and Graham, J.K. (2004): Evaluation of alternative cryoprotectants for preserving stallion spermatozoa. Theriogenology, 62:1056-1065.

Vidament, M.; Ecot, P.; Noue, P.; Bourgeois, C.; Magistrini, M. and Palmer, E. (2000): Centrifugation and addition of glycerol at 22 degres $C$ instead of 4 degrees $C$ improve postthaw motility and fertility of stallion spermatozoa. Theriogenology, 54: 907-919.

Vidament, M. (2005): French field results (19852005) on factors affecting fertility of frozen stallion semen. Anim. Reprod. Sci., 89: 115-134.

Webb, G.W.; Codi, L.; Burris, M.S.; Sarah, E.; Harmon, M.S.; Rachel, H. and Baker, M.S. (2011): Effects of Egg Yolk Source on the Cryopreservation of Stallion spermatozoa. J. Equine Vet. Sci., 31: 166-173.

Wells, M.E. and Awa, O.A. (1970): New technique for assessing acrosomal characteristics of spermatozoa. J. Dairy Sci ., 53: 327-332.

Wilhelm, K.M.; Graham, J.K. and Squires, E.L. (1996): Comparison of the fertility of cryopreserved stallion spermatozoa with sperm motion analyses, flow cytometric evaluation, and zona-free hamster oocyte penetration. Theriogenology, 46: 559-578.

Wundrich, K.; Paasch, U.; Leicht, M. and Glander, H.J. (2006): Activation of caspases in human spermatozoa during cryopreservation - an immunoblot study. Cell Tissue Bank, 7: 81-90.

\section{دراسة تأثير التركيزات المختلفة من سلفات دوديسيل الصوديوم وصفار البيض والجلسيرول على قابلية حيامن الخيول

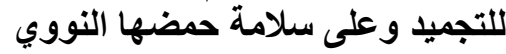

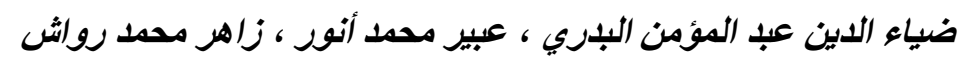

Email: diyabadry@hotmail.com

يهذف هذا البحث إلى تحسين تجميد السائل المنوي للخيول من خلال إضافة سلفات دوديسيل الصوديوم وصفار البيض و الجلسيرول

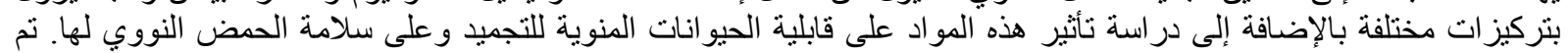

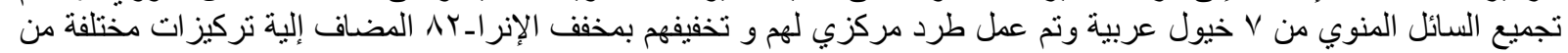

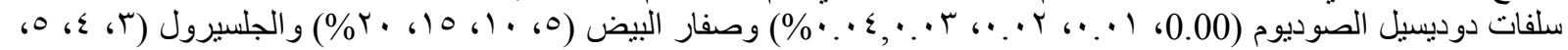

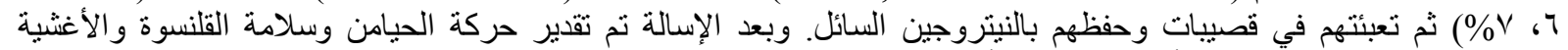

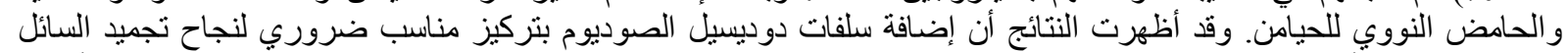

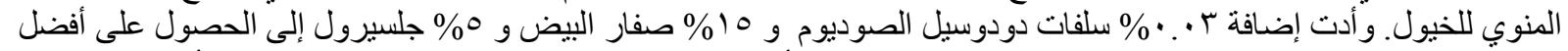

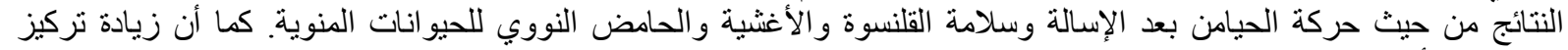

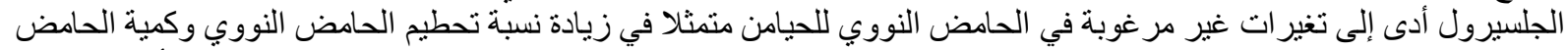

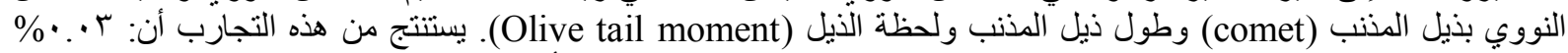

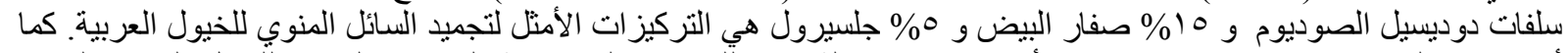

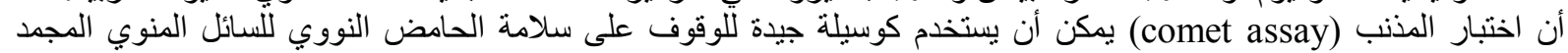

